\title{
Qualitative and Quantitative Late Blight Resistance in the Potato Cultivar Sarpo Mira Is Determined by the Perception of Five Distinct RXLR Effectors
}

\author{
Hendrik Rietman, ${ }^{1}$ Gerard Bijsterbosch, ${ }^{1}$ Liliana M. Cano, ${ }^{2}$ Heung-Ryul Lee, ${ }^{1}$ Jack H. Vossen, ${ }^{1}$ \\ Evert Jacobsen, ${ }^{1}$ Richard G. F. Visser, ${ }^{1}$ Sophien Kamoun, ${ }^{2}$ and Vivianne G. A. A. Vleeshouwers ${ }^{1}$ \\ ${ }^{1}$ Wageningen UR Plant Breeding, Wageningen University, P.O. Box 386, 6700 AJ, Wageningen, The Netherlands; ${ }^{2}$ The \\ Sainsbury Laboratory, Norwich, NR4 7UH, United Kingdom
}

Submitted 18 January 2012. Accepted 5 March 2012.

\begin{abstract}
Potato defends against Phytophthora infestans infection by resistance $(R)$-gene-based qualitative resistance as well as a quantitative field resistance. $R$ genes are renowned to be rapidly overcome by this oomycete, and potato cultivars with a decent and durable resistance to current $P$. infestans populations are hardly available. However, potato cultivar Sarpo Mira has retained resistance in the field over several years. We dissected the resistance of 'Sarpo Mira' in a segregating population by matching the responses to $P$. infestans RXLR effectors with race-specific resistance to differential strains. The resistance is based on the combination of four pyramided qualitative $\boldsymbol{R}$ genes and a quantitative $\boldsymbol{R}$ gene that was associated with field resistance. The qualitative $R$ genes include $R 3 a, R 3 b, R 4$, and the newly identified Rpi-Smira1. The qualitative resistances matched responses to avirulence (AVR)3a, AVR3b, AVR4, and AVRSmira1 RXLR effectors and were overcome by particular $P$. infestans strains. The quantitative resistance was determined to be conferred by a novel gene, Rpi-Smira2. It was only detected under field conditions and was associated with responses to the RXLR effector AvrSmira2. We foresee that effector-based resistance breeding will facilitate selecting and combining qualitative and quantitative resistances that may lead to a more durable resistance to late blight.
\end{abstract}

Potato, the third largest global food crop after wheat and rice, suffers from the devastating late blight disease that results in global yield losses of $16 \%$ (Haverkort et al. 2009). Late blight is caused by the oomycete Phytophthora infestans, which is renowned for triggering the Irish potato famine in the 1840s. The most sustainable strategy to protect potato plants from late blight is to breed broad-spectrum disease resistance $(R)$ genes into the cultivars. However, potato breeding is complicated because potato cultivars are highly heterozygous autotetraploid plants $(2 n=4 x=4 n)$ and suffer from acute inbreeding depression. On top of that, introduced $R$ genes are quickly defeated by "the $R$ gene destroyer" $P$. infestans, which has a remarkable capacity to rapidly adapt to resistant plants (Fry 2008; Haas et al. 2009; McDonald and Linde 2002). To minimize the chance of loss of resistance (defeat) of single intro-

Corresponding author: V. G. A. A. Vleeshouwers; Telephone +31317 487460; Fax +31 317 483457; E-mail: vivianne.vleeshouwers@wur.nl

* The $e$-Xtra logo stands for "electronic extra" and indicates that two supplementary tables are published online. duced $R$ genes, deploying multiple $R$ genes is considered one option for managing the late blight disease (Jones 2001; Park et al. 2009; Pink and Puddephat 1999). Also, quantitative resistance (so-called field resistance) is thought to result in a more durable resistance under field conditions (Fry 2008; Malcolmson 1969; Solomon-Blackburn et al. 2007; Wastie 1991). With late blight resistance breeding having been pretty much unsuccessful for more than 150 years (Müller and Black 1952), breeding for multi-genic resistance that includes field resistance remains a major challenge.

'Sarpo Mira' is one of the few potato cultivars that have been reported to retain resistance in the field for several years and is a candidate for delivering durable late blight resistance (Kim et al. 2011; White and Shaw 2010). The cultivar was bred by the Sárvári family in Eastern Hungary. However, to our knowledge, the pedigree is not described in the literature. Most likely, prebreeding leaned on the heritage of the Russian breeders Vavilov and Bukasov. For the development of other resistant potato cultivars, breeding studies with resistant Solanum germplasm have shown that a wealth of $R$ genes is present in wild Solanum section Petota species from South and Central America (Vleeshouwers et al. 2011a). For example, the highly resistant Mexican Solanum demissum was used for introgression of $R$ genes in potato differential clones $R 1$ to $R 11$ (Black et al. 1953). Among these, $R 1, R 2, R 3, R 4$, and $R 10$ have been widely used in potato breeding (Vleeshouwers et al. 2011b). Unfortunately, the origin or genetic constituents that determine the resistance of 'Sarpo Mira' are not known, and the degree to which resistance includes previously characterized $R$ genes could not be unambiguously determined using classical pathogen assays.

The emerging field of pathogen effector biology has valuable implications for breeding and deployment of disease resistance (Ellis et al. 2009; Vleeshouwers et al. 2011b). Effectoromics involves high-throughput screenings to assign activities to computationally predicted effector genes and has been successful in identifying a growing list of avirulence (Avr) effector genes and their matching $R$ genes (Oh et al. 2009; Vleeshouwers et al. 2008). To date, more than seven $R$-gene families with distinct functions and effector profiles have been identified and include, among others, $R 1, R 2, R 3 a, R 3 b$, and $R 4$ from $S$. demissum (Ballvora et al. 2002; Huang et al. 2005; Li et al. 2011; Lokossou et al. 2009; van Poppel et al. 2009). The matching Avr genes include Avrl, Avr2, Avr3a, Avr3b, and Avr4 and belong to the large superfamily of host-translocated RXLR effectors of Phytophthora spp. (Armstrong et al. 2005; Lokossou et al. 2009; van Poppel et al. 2008) (F. Govers, per- 
sonal communication). Knowledge of pathogen effector diversity and mode of action can be utilized to improve the use and deployment of late blight disease resistance to maximize the potential for durability (Vleeshouwers et al. 2011b).

In this study, we pursued an effectoromics approach to unravel the genetic basis of the resistance of 'Sarpo Mira'. First, we generated a population that segregates for resistance to $P$. infestans. We examined the avirulence spectra to different $P$. infestans strains and discovered that multiple $R$ genes determine qualitative resistance in 'Sarpo Mira'. Subsequently, we dissected the resistance by functionally testing effectors of $P$. infestans for inducing cell death responses in 'Sarpo Mira'. We identified multiple effectors, including two novel avirulence (AVR) effector proteins that induce specific patterns of responses, each matching a specific $R$ gene. Correlating responses to effectors with quantitative resistance in the field indicated that one of the novel $R$ genes seems to be responsible for field resistance. These data show that 'Sarpo Mira' contains a pyramid of at least five different $R$ genes that confer both qualitative and quantitative resistance to late blight.

\section{RESULTS}

\section{Sarpo Mira has complex genetic resistance based on multiple $\boldsymbol{R}$ genes.}

To dissect the genetic resistance of 'Sarpo Mira', we crossed the resistant 'Sarpo Mira' with the universally susceptible potato breeding clone 'RH89-039-16' (RH), a donor of the recently annotated potato genome (Potato Genome Sequencing Consortium 2011). A subset of 18 genotypes of the resultant 'Sarpo Mira' $\times$ RH population (3079) was subjected to disease tests by inoculating detached leaves with a panel of nine diverse $P$. infestans strains, which contain different race structures and are generally complex (Table 1). Qualitative resistance phenotypes were macroscopically scored. Resistant and susceptible phenotypes were observed as a hypersensitive response (HR) or as expanding, sporulating lesions, respectively. Distinct patterns of avirulence were detected among the nine $P$. infestans strains (Table 2). One strain, 89148-09, was avirulent on all offspring plants (pattern A). Three other strains (i.e., PIC99177, EC1, and 90128) were avirulent on at least the offspring plants 3079-4, 3079-6, 3079-7, 3079-8, 3079-16, 307927, 3079-28, 3079-31, 3079-37, and 3079-46 (pattern B). Two other distinct resistance patterns were observed for strain H30P04 (pattern C) and PIC99189 (pattern D). The strains PIC99183 and IPO428-2 were able to infect the entire offspring but not the 'Sarpo Mira' parent. In contrast, strain IPO-C was able to fully infect the 'Sarpo Mira' parent as well as the entire 3079 progeny under these test conditions. In some cases, intermediate levels of resistance were observed, which either could be attributed to remarkably high aggressiveness of a strain, such as PIC99183 (Champouret et al. 2009), or could point to the occurrence of other, partial resistance factors that were not further distinguished in these assays. Altogether, the observed distinct resistance patterns observed in these detached-leaf tests indicate that the resistance in 'Sarpo Mira' is genetically highly complex and is composed of several specific $R$ genes that are segregating in the 3079 population.

\section{Field resistance is segregating in the 'Sarpo Mira' population.}

Although $P$. infestans IPO-C could fully infect 'Sarpo Mira' under detached-leaf test conditions, we became aware that 'Sarpo Mira' does carry a certain level of resistance to this strain in the field. To test whether we could also dissect this field resistance, we planted 30 offspring of the 3079 population, including the same genotypes as were tested on leaves, in the field. In duplicated field trials in 2010 and 2011, potato plants were spray inoculated with strain IPO-C. For determining the quantitative levels of field resistance, we scored the percentages of infected plant tissue in time between 8 and 20 days postinoculation (dpi) and calculated the relative area

Table 1. Phytophthora infestans strains used in this study

\begin{tabular}{llll}
\hline Strain & \multicolumn{1}{c}{ Race $^{\mathbf{a}}$} & \multicolumn{1}{c}{ Origin } & \multicolumn{1}{c}{ Note or reference } \\
\hline $89148-09$ & 0 & The Netherlands & Champouret et al. 2009 \\
PIC99177 & 1.2 .3 .4 .7 .9 .11 & Mexico & Flier et al. 2002 \\
EC1 & 1.3 .4 .7 .11 & Ecuador & Armstrong et al. 2005 \\
90128 & 1.3 .4 .7 .8 .11 & The Netherlands & van West et al. 1998 \\
H30P04 & $3 a .7$ & Lab hybrid & Sibling of T30-4, Haas et al. 2009 \\
PIC99189 & 1.2 .5 .7 .10 .11 & Mexico & Flier et al. 2002 \\
PIC99183 & 1.3 .4 .5 .7 .8 .10 .11 & Mexico & Flier et al. 2002 \\
IPO-428-2 & 1.3 .4 .7 .8 .10 .11 & The Netherlands & Flier et al. 2003 \\
IPO-C & 1.2 .3 .4 .5 .6 .7 .10 .11 & Belgium & Champouret et al. 2009 \\
\hline
\end{tabular}

${ }^{a}$ Race nomenclature is based on ability to infect the differential set of potato carrying R1 to R11 (Black et al. 1953).

Table 2. Phytophthora infestans strains shows distinct patterns of avirulence on a segregating population from 'Sarpo Mira'a

\begin{tabular}{|c|c|c|c|c|c|c|c|c|c|c|c|c|c|c|c|c|c|c|c|c|c|}
\hline \multirow[b]{3}{*}{ Parents } & \multicolumn{21}{|c|}{ Virulence or avirulence phenotype } \\
\hline & \multicolumn{2}{|c|}{ Cultivar } & \multicolumn{19}{|c|}{ Offspring 3079} \\
\hline & Sarpo Mira & RH & 2 & 4 & 6 & 7 & 8 & 10 & 16 & 21 & 24 & 27 & 28 & 31 & 34 & 36 & 37 & 42 & 46 & 48 & Pattern \\
\hline 89148-09 & $\mathrm{R}$ & $\mathrm{S}$ & $\mathrm{R}$ & $\mathrm{R}$ & $\mathrm{R}$ & $\mathrm{R}$ & $\mathrm{R}$ & $\mathrm{R}$ & $\mathrm{R}$ & $\mathrm{R}$ & $\mathrm{R}$ & $\mathrm{R}$ & $\mathrm{R}$ & $\mathrm{R}$ & $\mathrm{R}$ & $\mathrm{R}$ & $\mathrm{R}$ & $\mathrm{R}$ & $\mathrm{R}$ & $\mathrm{R}$ & A \\
\hline PIC99177 & $\mathrm{R}$ & $\mathrm{S}$ & $\mathrm{R}$ & $\mathrm{R}$ & $\mathrm{R}$ & $\mathrm{R}$ & $\mathrm{R}$ & $\mathrm{R}$ & $\mathrm{R}$ & $\mathrm{S}$ & $\mathrm{S}$ & $\mathrm{R}$ & $\mathrm{R}$ & $\mathrm{R}$ & M & M & $\mathrm{R}$ & M & $\mathrm{R}$ & $\mathrm{M}$ & B \\
\hline EC1 & $\mathrm{R}$ & $\mathrm{S}$ & M & $\mathrm{R}$ & $\mathrm{R}$ & $\mathrm{R}$ & $\mathrm{R}$ & M & $\mathrm{R}$ & M & $\mathrm{S}$ & $\mathrm{R}$ & $\mathrm{R}$ & $\mathrm{R}$ & $\mathrm{S}$ & $\mathrm{S}$ & $\mathrm{R}$ & $\mathrm{S}$ & $\mathrm{R}$ & $\mathrm{S}$ & B \\
\hline 90128 & $\mathrm{R}$ & $\mathrm{S}$ & $\mathrm{S}$ & $\mathrm{R}$ & M & $\mathrm{R}$ & $\mathrm{R}$ & $\mathrm{S}$ & $\mathrm{R}$ & $\mathrm{S}$ & $\mathrm{S}$ & $\mathrm{R}$ & $\mathrm{R}$ & $\mathrm{R}$ & $\mathrm{S}$ & $\mathrm{S}$ & $\mathrm{R}$ & $\mathrm{S}$ & $\mathrm{M}$ & $\mathrm{S}$ & B \\
\hline H30P04 & $\mathrm{R}$ & $\mathrm{S}$ & $\mathrm{R}$ & $\mathrm{S}$ & $\mathrm{R}$ & $\mathrm{S}$ & M & $\mathrm{R}$ & $\mathrm{R}$ & $\mathrm{S}$ & $\mathrm{M}$ & $\mathrm{R}$ & $\mathrm{R}$ & $\mathrm{R}$ & $\mathrm{R}$ & $\mathrm{S}$ & $\mathrm{R}$ & $\mathrm{S}$ & $\mathrm{R}$ & $\mathrm{S}$ & $\mathrm{C}$ \\
\hline PIC99189 & $\mathrm{R}$ & $\mathrm{S}$ & $\mathrm{R}$ & $\mathrm{S}$ & $\mathrm{R}$ & $\mathrm{S}$ & $\mathrm{S}$ & $\mathrm{R}$ & $\mathrm{R}$ & $\mathrm{R}$ & $\mathrm{R}$ & $\mathrm{R}$ & $\mathrm{R}$ & $\mathrm{R}$ & $\mathrm{R}$ & $\mathrm{R}$ & $\mathrm{R}$ & $\mathrm{R}$ & $\mathrm{R}$ & $\mathrm{R}$ & D \\
\hline PIC99183 & M & $\mathrm{S}$ & $\mathrm{S}$ & $\mathrm{S}$ & $\mathrm{S}$ & $\mathrm{S}$ & $\mathrm{S}$ & $\mathrm{S}$ & $\mathrm{S}$ & $\mathrm{S}$ & $\mathrm{S}$ & $\mathrm{S}$ & $\mathrm{S}$ & $\mathrm{S}$ & $\mathrm{S}$ & $\mathrm{S}$ & $\mathrm{S}$ & $\mathrm{S}$ & $\mathrm{S}$ & $\mathrm{S}$ & $\ldots$ \\
\hline IPO428-2 & $\mathrm{R}$ & $\mathrm{S}$ & $\mathrm{S}$ & $\mathrm{S}$ & $\mathrm{S}$ & $\mathrm{S}$ & $\mathrm{S}$ & $\mathrm{S}$ & $\mathrm{S}$ & $\mathrm{S}$ & $\mathrm{S}$ & $\mathrm{S}$ & $\mathrm{S}$ & $\mathrm{S}$ & $\mathrm{S}$ & $\mathrm{S}$ & $\mathrm{S}$ & $\mathrm{S}$ & $\mathrm{S}$ & $\mathrm{S}$ & $\ldots$ \\
\hline IPO-C & $\mathrm{S}$ & $\mathrm{S}$ & $\mathrm{S}$ & $\mathrm{S}$ & $\mathrm{S}$ & $\mathrm{S}$ & $\mathrm{S}$ & $\mathrm{S}$ & $\mathrm{S}$ & $\mathrm{S}$ & $\mathrm{S}$ & $\mathrm{S}$ & $\mathrm{S}$ & $\mathrm{S}$ & $\mathrm{S}$ & $\mathrm{S}$ & $\mathrm{S}$ & $\mathrm{S}$ & $\mathrm{S}$ & $\mathrm{S}$ & $\ldots$ \\
\hline
\end{tabular}

${ }^{a}$ A detached-leaf assay was performed on the parents (Sarpo Mira and 'RH89-039-16' [RH]) and offspring of population 3079 to score for qualitative resistance to various strains of $P$. infestans. Resistant (R), susceptible (S), and intermediate (M) phenotypes were observed. Various resistance patterns (A to D) were distinguished. 
under the disease progress curve (AUDPC) values (Fig. 1). 'Sarpo Mira' remained fully resistant for at least 14 dpi and only $4 \%$ of the plant tissue was blighted at 20 dpi. This indicates that, indeed, a certain level of field resistance to strain IPO-C is present in this potato cultivar. The susceptible parent RH was almost fully (98\%) diseased at 20 dpi. The offspring plants of 3079 showed a range of intermediate levels of resistance between both parents, in line with the theory that field resistance is typically controlled by so-called minor genes that confer quantitative phenotypes (Gebhardt and Valkonen 2001). In both years, similar results were obtained. In summary, we conclude that field resistance to strain IPO-C segregates in the 'Sarpo Mira' population 3079 even though these plants are fully susceptible to this strain in detached-leaf assays.

\section{Effectoromics screens to dissect late blight resistance in 'Sarpo Mira'.}

Effectoromics, or high-throughput screens of plants for response to pathogen effectors, has emerged as a powerful approach to identify and define resistance specificities in Solanum spp. germplasm (Vleeshouwers et al. 2008). To test whether the complex resistance of 'Sarpo Mira' could be further dissected using effectors in addition to $P$. infestans strains, we performed an effector screen with an exhaustive collection of 234 predicted RXLR effectors selected from the P. infestans genome sequence (Haas et al. 2009). We transiently expressed the effectors in leaves of 'Sarpo Mira' plants by agroinfiltration, in nine replicates. The development of cell death symptoms was visually scored on a scale from 0 to $100 \%$. Of the 234 tested effectors, we found that 30 effectors triggered various levels of cell death in 'Sarpo Mira' (Table 3).

To examine whether responses to effectors co-segregate with specific resistances, we selected 19 effectors that showed the highest levels of cell death $(>85 \%)$ in 'Sarpo Mira' and used agroinfiltration to express them in population 3079 plants. Subsequently, we scored the plants for occurrence of cell death responses and looked for patterns of co-segregation with specific resistance to the $P$. infestans strains (Table 4). Three effector recognition patterns matched the avirulence profiles of $P$. infestans strains; namely, the responses caused by AVR3b (pattern A), PITG_07550 (pattern B), and AVR4 (pattern C).

Pattern A was found for 14 effectors, which caused cell death in the entire tested population. Among these is Avr $3 b$ (PITG_18215), the matching $A v r$ gene to $R 3 b$ (Li et al. 2011). This suggests that $R 3 b$, or an $R$ gene with $R 3 b$ specificity, is present in 'Sarpo Mira'. Indeed, strain 89148-09, a race 0 that is avirulent on $R 3 b$ potato (Table 1), is also avirulent on 'Sarpo Mira' and all tested 3079 progeny plants (Table 2).

Pattern B matches the response to PITG_07550 and corresponds to the specific resistance to $P$. infestans strains PIC99177, EC1, and 90128. This pattern of responses does not match any of the known $R$ genes and, therefore, indicates presence of an as-yet-unknown $R$ gene in 'Sarpo Mira'. We designated this gene Rpi-Smiral, and the matching PITG_07750 as the candidate for AvrSmiral.

Pattern C reflects the response to AVR4 (PITG_07387) and specific resistance to $\mathrm{H} 30 \mathrm{P} 04$. Indeed, strain $\mathrm{H} 30 \mathrm{P} 04$ is avirulent on $R 4$ potato (Table 1 ). The data suggest that $R 4$, or an $R$ gene with $R 4$ specificity, is present in 'Sarpo Mira' and segregating in population 3079 .

In addition to these three patterns that clearly match response to single effectors (patterns A to $\mathrm{C}$ ), three other response patterns (patterns D to F) could be distinguished using effector assays. In case of responses to AVR3a (pattern F) and AVR4 (pattern C), their combined pattern (D) matches the avirulence profile to strain PIC99189. These data suggest that this strain has both Avr3a and Avr4, which is also in agreement with its race structure (Table 1). In line with this, the presence of Avr $3 a$ and Avr4 coding genes was predicted in the genome of PIC99189 genome by alignment of Illumina reads of PIC99189 to the reference genome strain T304 (Raffaele et al. 2010) (L. Cano, and S. Kamoun, unpublished).

To further examine the correlation between effector response and resistance patterns, we performed an analysis of variance (ANOVA) on results from the detached-leaf tests and agroinfiltrations (Supplementary Table S1). Patterns B, C, and D were, indeed, statistically supported $(P$ values $<0.0001)$. Pattern A could not be tested because response to AVR3b did not segregate in the population.

In summary, effectoromics revealed additional patterns of response to $P$. infestans and four effectors that are recognized (AVR3a, AVR3b, AVR4, and AVRSmira1) to match avirulence patterns of $P$. infestans strains (Table 4). We summarize the key features these four Avr genes of $P$. infestans in Figure 2, based on the genome data of the reference strain T30-4 (Haas et al. 2009): i) the modular structure that is typical for RXLR effectors with an N-terminal (signal peptide) domain, RXLR motif, and C-terminal effector domain; ii) expression of the $A v r$ genes is induced during the early biotrophic phase of the infection; and iii) the $A v r$ genes occur in the gene-sparse regions of the genome. The new AvrSmiral fits all these criteria that are typical for all Avr genes of $P$. infestans that have been identified thus far (Vleeshouwers et al. 2011b).

\section{Response to PITG_07558 correlates with field resistance and reveals a fifth resistance gene, Rpi-Smira2, that confers quantitative late blight resistance.}

Responses to the remaining effector, PITG_07558, did not match the resistance profiles of any of the examined $P$. infestans strains that were assayed on detached leaves. Therefore, we decided to test whether these responses matched the observed field resistance in 'Sarpo Mira' (Table 2; Fig. 1). An

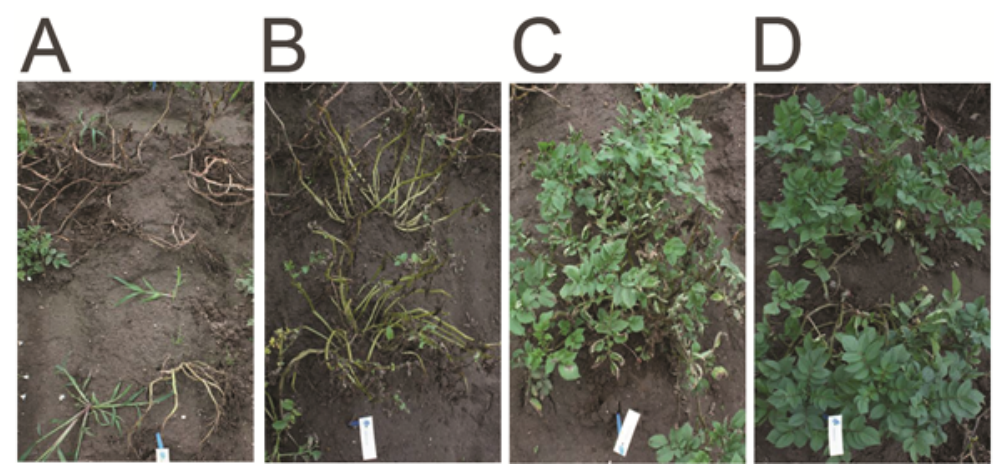

Fig. 1. Photographs of potato in the field trail of 2010 at 34 days postinoculation. A, Susceptible parent 'RH89-039-16'; two partially resistant offspring plants B, 3079-16 and C, 3079-48; and D, the field resistant 'Sarpo Mira'. 
ANOVA analysis on the average AUDPC values of both field trials and responses to the effectors revealed that responses to PITG_07558 significantly correlated with field resistance, especially during the first 3 weeks after infection $(P<0.0025)$ (Fig. 3). These data show that recognition of one effector, PITG_07558, co-segregates with field resistance, conferred by a fifth gene we named Rpi-Smira2. We designated PITG_ 07558 as the candidate AvrSmira2 gene. Similar to the other four Avr genes, AvrSmira 2 occurs in the gene-sparse regions of the genome and has the modular structure that is typical for RXLR effectors, with an N-terminal (signal peptide) domain, RXLR motif, and C-terminal effector domain (Fig. 2). However, compared with the other Avr genes, expression of AvrSmira2 is induced at earlier time points (i.e., 16 versus $48 \mathrm{~h}$ postinoculation [hpi]). Despite this shift in timing of upregulation, AvrSmira 2 is expressed during early biotrophic phases, which can lead to recognition by plant receptors and initiation of avirulence activity.

Table 3. RXLR effectors that trigger cell death response on 'Sarpo Mira'

\begin{tabular}{|c|c|c|c|c|c|c|c|c|c|}
\hline \multicolumn{2}{|l|}{$\overline{\text { Effector }}$} & \multicolumn{2}{|c|}{ SignalP $^{b}$} & \multirow[b]{2}{*}{ RXLR } & \multirow[b]{2}{*}{$\begin{array}{c}\text { RXLR } \\
\text { tribe }^{d}\end{array}$} & \multicolumn{2}{|c|}{ Expression in potato $^{c}$} & \multicolumn{2}{|c|}{ Response } \\
\hline $\begin{array}{l}\text { Gene or construct } \\
\text { ID }\end{array}$ & $\begin{array}{c}\text { Gene } \\
\text { annotation }\end{array}$ & $\begin{array}{l}\text { HMM } \\
\text { prob. }\end{array}$ & $\begin{array}{l}\text { NN mean } \\
\text { NS score }\end{array}$ & & & $\begin{array}{c}16 \\
\text { hpi }\end{array}$ & $\begin{array}{c}48 \\
\text { hpi }\end{array}$ & $\begin{array}{c}\text { 'Sarpo Mira' } \\
(\%)^{\mathrm{e}}\end{array}$ & $\begin{array}{c}\text { Pattern in } \\
\text { 3079 }^{f}\end{array}$ \\
\hline PITG_12761 & $\ldots$ & 0.999 & 0.791 & RLLR & 1 & 0.73 & 0.04 & 31 & na \\
\hline PITG_15039 & $\ldots$ & 0.993 & 0.928 & RILV & 1 & 0.83 & 1.12 & 100 & Pattern A \\
\hline PITG_22880 & $\ldots$ & 0.999 & 0.928 & na & 1 & 0.74 & 0.09 & 100 & Pattern A \\
\hline PITG_07558 & AvrSmira2 & 1.000 & 0.963 & RSLR & 2 & 1.11 & 0.24 & 100 & Pattern E \\
\hline PITG_09660 & $\ldots$ & 0.999 & 0.948 & na & 2 & 1.38 & 0.81 & 94 & Pattern G \\
\hline PITG_04085 & $\ldots$ & 1.000 & 0.879 & RSLR & 5 & -0.10 & 2.53 & 92 & Pattern A \\
\hline PITG_04090 & $\ldots$ & 1.000 & 0.849 & RSLR & 5 & -0.62 & 2.44 & 36 & na \\
\hline PITG_04097 & $\ldots$ & 1.000 & 0.786 & RSLR & 5 & 1.40 & 1.28 & 92 & Pattern A \\
\hline PITG_18683 & $\ldots$ & 1.000 & 0.862 & RSLR & 5 & -0.54 & 2.61 & 89 & Pattern A \\
\hline PITG_20300 & $\ldots$ & 1.000 & 0.849 & RSLR & 5 & -1.13 & 2.45 & 83 & Pattern A \\
\hline PITG_20301 & $\ldots$ & 1.000 & 0.889 & RSLR & 5 & -0.12 & 2.39 & 100 & Pattern A \\
\hline PITG_20303 & $\ldots$ & 1.000 & 0.880 & RSLR & 5 & 0.16 & 2.39 & 90 & Pattern A \\
\hline PITG_04169 & $\ldots$ & 0.995 & 0.918 & RSLR & 10 & 0.13 & 0.65 & 92 & Pattern A \\
\hline PITG_15718 & $\ldots$ & 0.994 & 0.754 & RSLR & 14 & 1.72 & 0.45 & 22 & na \\
\hline PITG_05750 & $\ldots$ & 1.000 & 0.934 & RLLR & 29 & 1.52 & 1.04 & 33 & na \\
\hline PITG_16275 & $\ldots$ & 0.999 & 0.869 & RLLS & 42 & 0.75 & 2.55 & 11 & na \\
\hline PITG_15162 & $\ldots$ & 0.999 & 0.903 & RRLR & 43 & 1.74 & 0.58 & 22 & na \\
\hline PITG_07387 & Avr4 & 0.999 & 0.850 & RFLR & 52 & 0.03 & 2.00 & 100 & Pattern C \\
\hline PITG_10540 & $\ldots$ & 0.997 & 0.747 & RFLR & 57 & -0.06 & 1.37 & 85 & Pattern A \\
\hline PITG_14371 & $A v r 3 a(\mathrm{EM})$ & na & na & RLLR & 58 & 0.72 & 2.20 & na & na \\
\hline PITG_14371_KI ${ }^{\mathrm{g}}$ & $A v r 3 a(\mathrm{KI})$ & na & na & RLLR & 58 & na & na & 100 & Pattern F \\
\hline PITG_14374 & $\ldots$ & 0.992 & 0.724 & RFLR & 58 & 0.44 & 0.91 & 100 & Pattern A \\
\hline PITG_04049 & $\ldots$ & 0.997 & 0.744 & QFLR & 67 & 0.49 & 2.47 & 14 & na \\
\hline PITG_14360 & $\ldots$ & 0.999 & 0.953 & RILR & 72 & 0.97 & 0.93 & 21 & na \\
\hline PITG_16294 & $\ldots$ & 1.000 & 0.933 & RLLR & 97 & 0.51 & 2.63 & 6 & na \\
\hline PITG_07550 & AvrSmiral & 1.000 & 0.947 & RLLR & 117 & 1.66 & 2.24 & 100 & Pattern B \\
\hline PITG_18215 & $A v r 3 b$ & 0.999 & 0.857 & RSLR & 124 & 1.51 & 3.07 & 100 & Pattern A \\
\hline PITG_23129 & $\ldots$ & 0.956 & 0.452 & RLLR & 128 & 1.38 & 1.28 & 72 & Pattern A \\
\hline PITG_23131 & $\ldots$ & 0.983 & 0.831 & RLLR & 128 & 0.97 & 1.09 & 100 & Pattern A \\
\hline PITG_19942 & $\ldots$ & 0.998 & 0.948 & RYLK & 237 & 0.62 & 1.23 & 34 & na \\
\hline pMDC32 & Neg control & $\ldots$ & $\ldots$ & $\ldots$ & $\ldots$ & na & na & 0 & None \\
\hline R3a:Avr3a & Pos control & $\ldots$ & $\ldots$ & $\ldots$ & $\ldots$ & na & na & 100 & Pattern A \\
\hline
\end{tabular}

Table 4. Segregation of response to RXLR effectors in 20 offspring genotypes of the 'Sarpo Mira' (SM) × 'RH89-039-16' (RH) population 3079a

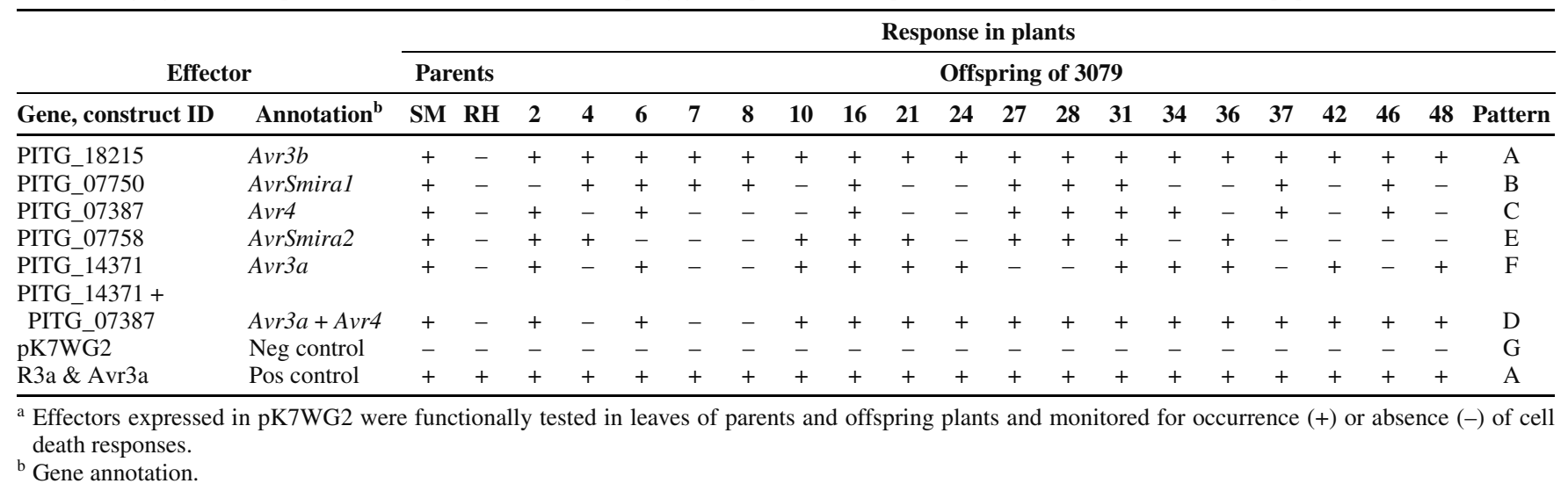


AvrSmiral has diverse genetic variants with similar specificity.

AvrSmiral (PITG_07550) originates from the P. infestans reference strain T30-4. To detect additional variants of AvrSmiral, we performed a polymerase chain reaction survey on the $9 P$. infestans strains (Table 1). We detected a total of 22 singlenucleotide proteins (SNP) when comparing the homologous coding sequences of PITG_07550. Of these, 20 SNP are found in the C-terminal effector domain of PITG_07550 (the signal peptide was not analyzed). Of 20 C-terminal SNP, 14 represent nonsynonymous substitutions that lead to 13 polymorphic amino acid residues at the C-terminal effector domain of PITG_07550. In total, we identified 12 different AVRSmira1 amino acid variants (Fig. 4A).

Phylogenetic analyses of the protein alignment of the 12 AVRSmira1 variants using maximum parsimony algorithms showed a grouping into two broad classes, I and II (Fig. 4B). Phylogenetic trees based on neighbor-joining or minimal evolution resulted in similar clustering (not shown).

To investigate whether AvrSmira1 is also under diversifying selection, we assessed positive selection per residue on the obtained AvrSmira1 variants. With model M1, M2, and M8, eight or nine amino acids were identified, of which the eight were always overlapping. Among those eight, four amino acids on positions $128,130,156$, and 170 were significantly under diversifying selection (Fig. 4A; Supplementary Table S2).

To study whether the genetic variants of AVRSmiral in $P$. infestans strains can explain avirulence properties on RpiSmiral-containing potato, we compared their phylogenetic clustering and significant amino acids with resistance profiles obtained from progeny plants (Tables 5 and 6). Most $P$. infestans strains are able to infect one or more progeny genotypes that respond to the AVRSmiral candidate, which indicates that Rpi-Smiral is defeated by most tested strains. However, the strains EC1 and PIC99177 are most likely avirulent on RpiSmiral plants because they were not able to infect any of the AVRSmira1-responding progeny plants (Table 2). These strains lack class I AVRSmira1 variants, and lack a methionine

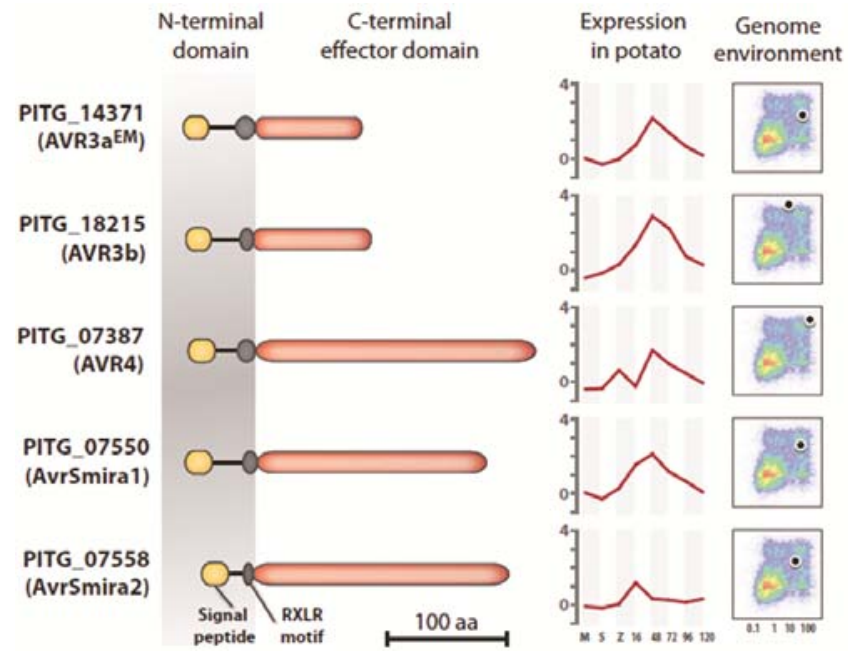

Fig. 2. Features of the five effectors that have avirulence (AVR) activity on 'Sarpo Mira'. The figure depicts AVR3a, AVR3b, AVR4, AVRSMira1, and AVRSMira2. The domain structure of Phytophthora infestans AVR proteins shows a typical RXLR effector modular structure with N-terminal (signal peptide) domain, RXLR motif, and C-terminal effector domain. Graphs representing the expression in potato illustrate a time course expression pattern of the Avr genes during 16 to $120 \mathrm{~h}$ of infection of potato by genome reference strain T30-4, with the $y$ axis showing gene induction (Haas et al. 2009). Genome environment heat maps are two-dimensional plots of $5^{\prime}$ and $3^{\prime}$ intergenic distance for all P. infestans genes (Haas et al. 2009). or arginine on amino acids 156 and 170, respectively (Fig. 4A). This suggests that class II variants are potentially sufficient to mediate avirulence on Rpi-Smiral plants. To test whether genetic variants can induce cell death on 'Sarpo Mira', we expressed variants 1, 4, 5, 11, 8, 9, 10, 14, and 15 in Agrobacterium spp. and tested them by agroinfiltration in two plants. All variants were able to induce cell death; however, variant PITG_07550_10 seemed to induce slightly lower levels of cell death (data not shown). Taken together, our results show that AVRSmira1 is a highly polymorphic gene that is under positive selection in $P$. infestans. It remains to be determined which characteristics of this gene are important for its avirulence activity on 'Sarpo Mira'.

\section{DISCUSSION}

The potato 'Sarpo Mira' has been proposed to carry valuable and potentially durable resistance to $P$. infestans (Kim et al. 2011; White and Shaw 2010). In this study, we show that the genetic basis of late blight resistance in 'Sarpo Mira' is highly complex, consisting of at least five different $R$ genes that confer qualitative and quantitative resistance to late blight. We dissected this multifaceted resistance using effector assays and a differential set of $P$. infestans strains. Profiling the effector responses enabled a better discrimination of specific $R$ gene activities than pathogen assays with a collection of $P$. infestans strains. This study vividly illustrates the value of integrating effector screens (effectoromics) with the genetic characterization of plant breeding material (Vleeshouwers et al. 2011b). With these five effectors at hand, breeding of 'Sarpo Mira'-derived potato can proceed in a more precise and efficient fashion.

Our effectoromics approach enabled the dissection of late blight resistance in 'Sarpo Mira' into distinct components. First, the qualitative $R$ genes $R 3 a, R 3 b$, and $R 4$ could be accurately identified and profiled using $A v r 3 a, A v r 3 b$, and $A v r 4$, independently of other $R$ genes. This could not be performed solely using differential $P$. infestans strains, because multiple $R$ genes independently segregate in the progeny and can mask other recognition specificities. Second, we discovered novel $R$

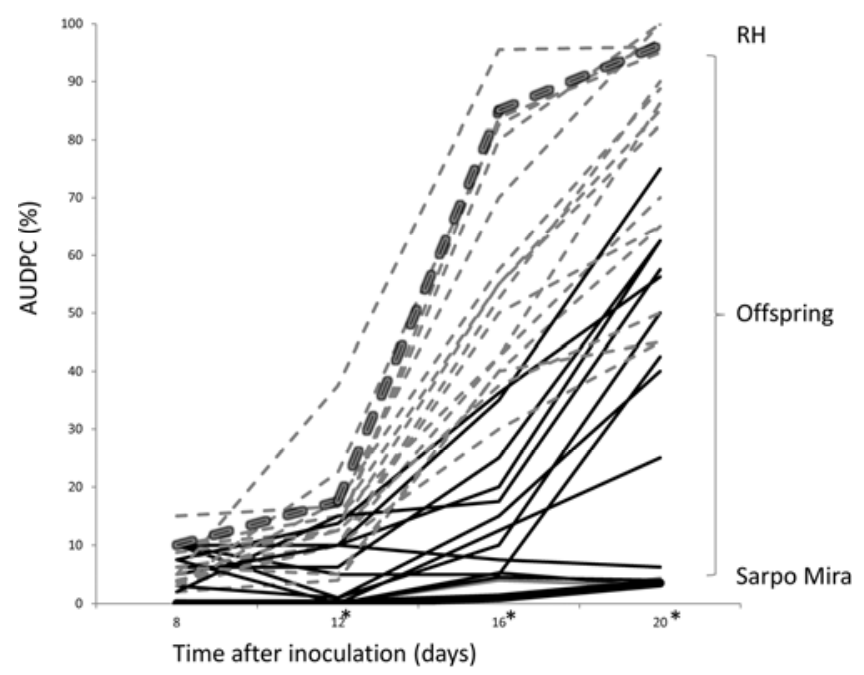

Fig. 3. Quantitative field resistance of 'Sarpo Mira' to virulent Phytophthora infestans IPO-C. Levels of late blight infection for 'Sarpo Mira', 'RH89-039-16' (RH), and their offspring are plotted from 8 to 20 days postinoculation (dpi) from the field trail in 2011. 'Sarpo Mira' and partially resistant offspring genotypes showed cell death to PITG_07558 (solid lines), whereas $\mathrm{RH}$ and remaining offspring genotypes failed to recognize the effector (dashed lines). Significance of correlation between response to PITG_07558 and field resistance is indicated $(*)$ for each time point at the $x$ axis for $P$ values lower than 0.001 . 
A

$\begin{array}{ll} & \text { \#PITG_07550_1 } \\ & \text { \#PITG_07550_4 } \\ & \text { \#PITG_07550_5 } \\ & \text { \#PITG_07550_6 } \\ \text { I } & \text { \#PITG_07550_7 } \\ & \text { \#PITG_07550_8 } \\ & \text { \#PITG_07550- } \\ & \text { \#PITG_07550_10 } \\ & \text { \#PITG_07550_11 } \\ & \text { \#PITG_07550_13 } \\ \text { II } & \text { \#PITG_07550_14 } \\ & \text { \#PITG_07550_15 }\end{array}$

MRLSSTFLVA AAALLVLSDV VSAATVTKVS AMNVPNVAKP VEVAPVKDAR LLRSESRKQT
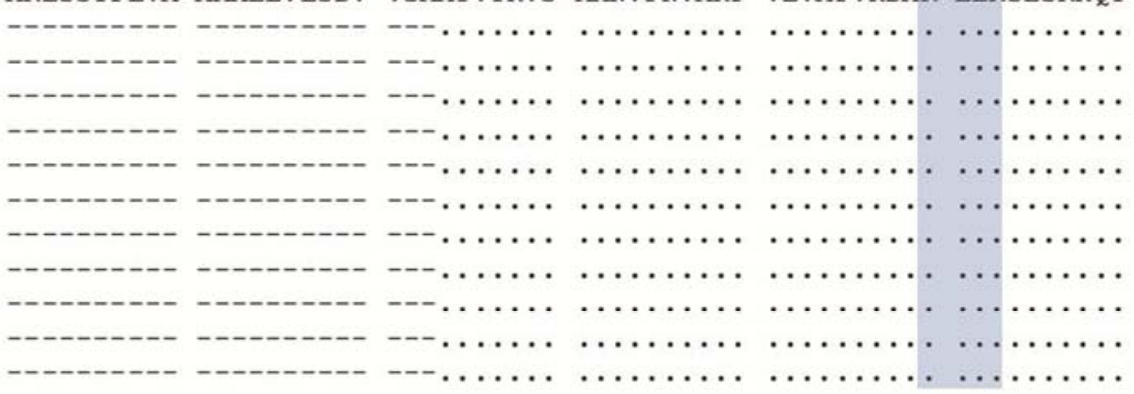

DEER

\#PITG $07550 \quad 1$ \#PITG_07550 ${ }^{-} 4$ \#PITG_07550_5 \#PITG $07550^{-} 6$ \#PITG_07550_7 \#PITG_07550-8 \#PITG-07550 \#PITG_07550_10 \#PITG_07550_11 \#PITG_07550_13 \#PITG $07550-14$ \#PITG_07550_15

DVEDFEDEER KIQTSLIDDA FKGLGRTDDA AKKLLANDDA MAKKLAALNK QQGEADNAKF
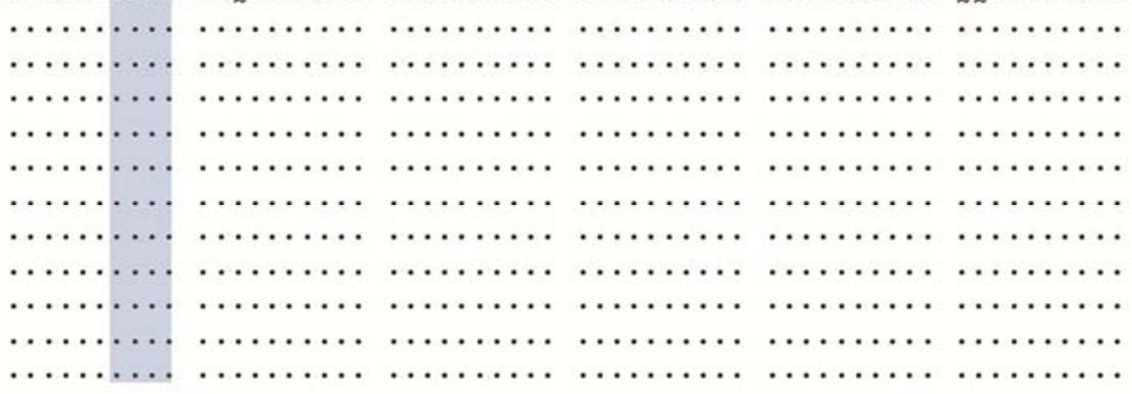

$\mathrm{Q}^{128} \mathrm{M}^{130}$

$M^{156} \quad R^{170}$

\#PITG_07550_1 \#PITG_07550_4 \#PITG_07550_5 \#PITG_07550_6

I \#PITG $07550^{-} 7$ \#PITG_07550_8 \#PITG 07550 \#PITG_07550_10 \#PITG $07550^{-} 11$ \#PITG $07550^{-} 13$ LANLWMRQNM RPEDLRLLTK TPVNKKAYQE FLVQYMKKHH SLKPGPQANQ KITREGAQIL $\ldots \ldots \ldots$ $\ldots \ldots$ R.K .....R.K. $\cdots \cdots \cdots$ $\ldots \ldots \ldots \mathrm{K}$

$\ldots \ldots \ldots$ $\ldots \ldots \ldots \ldots \ldots \ldots \ldots \ldots \ldots \ldots \ldots \ldots \ldots \ldots \ldots$ $\ldots \ldots \ldots \ldots$

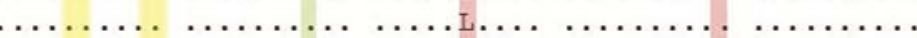
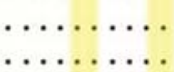

k........ ................

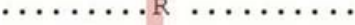

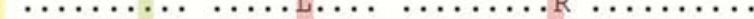

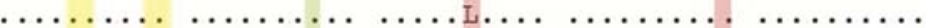

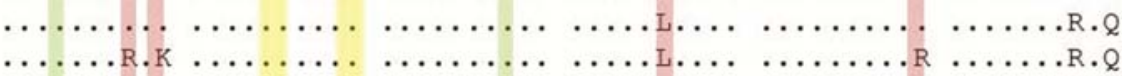

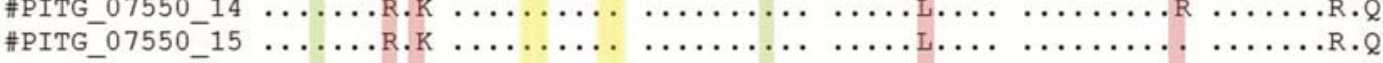
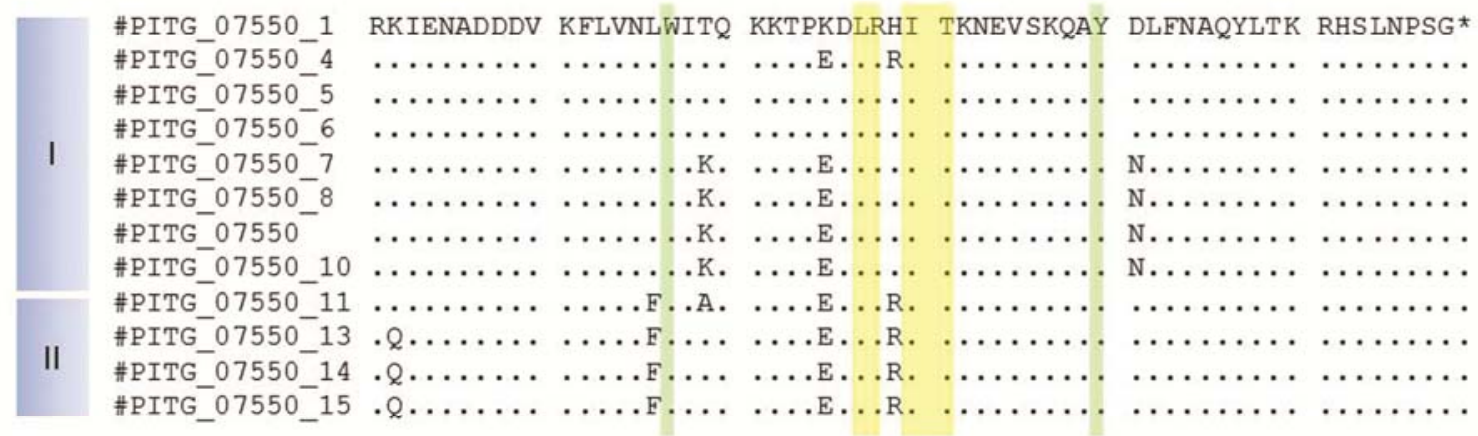

B

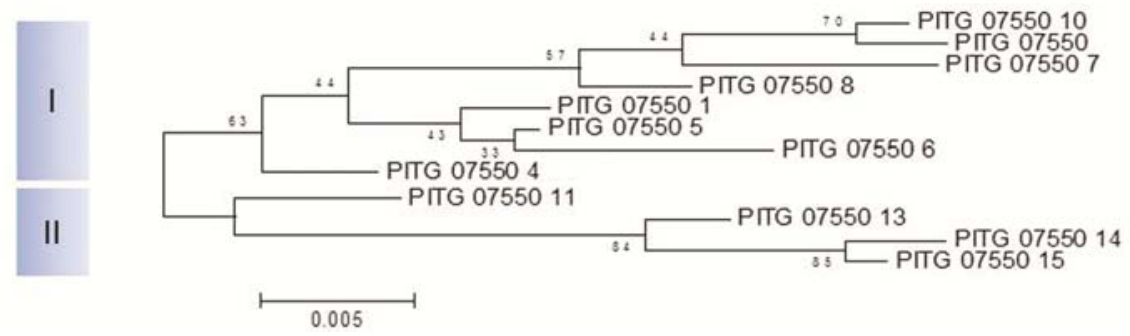

Fig. 4. Genetic variants of the AVRSmira1 candidate PITG_07550 in Phytophthora infestans strains. A, Alignment of amino acid sequences of AVRSmira1 variants, after the signal peptide. The RXLR-DEER motifs are marked in gray, amino acids under diversifying selection in red, and two putative WY domains in yellow and green. B, Neighbor-joining tree reveals two classes of AVRSmira1 variants. Bootstrap values of 1,000 replicates are indicated at the nodes. 
genes based on unique response profiles to two novel avirulence effector candidates, AVRSmira1 and AVRSmira2. This would have been much more challenging using $P$. infestans strains, especially given that these two $R$ genes co-occur with three other resistance specificities. Third, in addition to detecting qualitative $R$ genes such as $R 3 a, R 3 b, R 4$, and Rpi-Smiral, the effector assays unraveled Rpi-Smira2, a gene that confers quantitative field resistance. Because partial resistance conferred by Rpi-Smira 2 is often overshadowed by $R$ genes with stronger effects, its detection is challenging, if not impossible, with $P$. infestans strains alone. In this case, the Rpi-Smira2 partial resistance could only be scored in field trials and not in laboratory assays. One challenge for scoring such a type of resistance is that field trials are vulnerable to cross infections by airborne strains with unknown specificities, thereby greatly complicating the phenotyping. With the discovery of the AVRSmira2 effector, we now have a straightforward and precise assay for Rpi-Smira2, which could accelerate and facilitate the breeding and cloning of this gene.

All five RXLR effector genes fulfill the typical features of oomycete $A v r$ genes as they encode for modular proteins that contain an N-terminal signal peptide followed by a RXLR motif and a C-terminal effector domain, occur in gene-sparse regions of the $P$. infestans genome, and are induced during the early biotrophic phases of infection (Fig. 2). Avirulence activities of AVR3a, AVR3b, and AVR4 correspond to the race profiles, the presence or absence in genome sequence of T30-4 and PIC99189, and published genotype-phenotype relationships (Armstrong et al. 2005; Li et al. 2011; van der Lee et al. 2001; van Poppel et al. 2008). The newly identified AvrSmiral is induced during the biotrophic phases of infection in P. infestans based on microarray gene expression data. Also, a partial sequence of AvrSmiral is present in an expressed sequence tag library from germinating cysts of $P$. infestans (GenBank accession CV920103). Small-scale genetic variation studies confirmed that AVRSMira1 is polymorphic within nine analyzed P. infestans strains, similar to some other AVR proteins (e.g.,
AVRblb1 of P. infestans) (Champouret et al. 2009; Halterman et al. 2010). We identified up to 12 different variants of AVRSmira1 that share 13 polymorphic amino acids. These polymorphisms mainly occurred at the C-terminal effector domain, which is known to be involved in recognition specificity (Win et al. 2007). Correlating the genetic variants with virulence on Rpi-Smiral plants revealed the absence of class I variants carrying the $\mathrm{M}^{156}$ and $\mathrm{R}^{170}$ polymorphisms in avirulent strains, indicating that these genes are not essential for avirulence. The amino acids found under diversifying selection and, for example, a weaker degree of recognition or lower expression levels of the effector genes in virulent isolates could play a role in determining avirulence (Oh et al. 2009; Qutob et al. 2009).

The other newly identified Avr candidate AvrSmira2 was induced only at 16 hpi during a time course of infection on potato (Fig. 2). This is earlier than the timing for gene induction from other known avirulence effector genes of $P$. infestans, which peak at 48 hpi (Haas et al. 2009; Vleeshouwers et al. 2011b) (Fig. 2). This transient and early induction profile of AvrSmira2 could explain why its cognate $R$ gene, Rpi-Smira2, only confers quantitative resistance. The extent to which expression profiles, genetic variation, or other factors explain the recognition of this effector in relation to field resistance remains to be investigated.

Field resistance to late blight has been claimed to be durable in various studies (Fry 2008; Stewart et al. 2003; Van Der Plank 1971; Wastie 1991). Given that $R$ genes are typically quickly defeated because of the ability of $P$. infestans to rapidly adapt and evolve (Raffaele et al. 2010; Wastie 1991), many potato breeders were caught by naïve optimism that breeding for "field resistance" should prove more durable. This has led to the misguided concept of breeding for so-called " $R$-gene-free" potato plants that carry field resistance but lack known $R$ genes. However, the genetic basis of field resistance has remained unclear, mainly because the weak phenotypes are too difficult to follow in the genetically complex potato and

Table 5. Overview of genetic diversity of AVRSmira1 in relation to virulence on the 'Sarpo Mira' $\times$ 'RH89-039-16' population 3079a

\begin{tabular}{|c|c|c|c|c|c|c|c|c|c|c|c|c|c|c|}
\hline \multirow[b]{2}{*}{ Variant } & \multirow[b]{2}{*}{ Class } & \multicolumn{4}{|c|}{$\begin{array}{l}\text { Positive selected } \\
\text { amino acid sites }\end{array}$} & \multicolumn{9}{|c|}{ Phytophthora infestans strains } \\
\hline & & 128 & 130 & 156 & 170 & 89148-09 & $\begin{array}{c}\text { PIC } \\
99177\end{array}$ & EC1 & 90128 & Н30Р04 & $\begin{array}{c}\text { PIC } \\
99189\end{array}$ & $\begin{array}{c}\text { PIC } \\
99183\end{array}$ & $\begin{array}{c}\text { IPO } \\
428-2\end{array}$ & IPO-C \\
\hline$\overline{\text { PITG_07550 }}$ & $\mathrm{I}$ & Q & $\mathrm{K}$ & $\mathrm{M}$ & $\mathrm{R}$ & $\ldots$ & $\ldots$ & $\ldots$ & $\ldots$ & $\ldots$ & $\ldots$ & $\ldots$ & $\ldots$ & $\ldots$ \\
\hline PITG_07550_1 & I & Q & $\mathrm{K}$ & M & Q & $\mathrm{X}$ & $\ldots$ & $\ldots$ & $\ldots$ & $\mathrm{X}$ & $\ldots$ & $\ldots$ & $\mathrm{X}$ & $\mathrm{X}$ \\
\hline PITG_07550_4 & I & Q & K & M & Q & $X$ & $\ldots$ & $\ldots$ & $\ldots$ & $\ldots$ & $\ldots$ & $\ldots$ & $\ldots$ & $\ldots$ \\
\hline PITG_07550_5 & I & Q & $\mathrm{K}$ & $\mathrm{L}$ & Q & $\ldots$ & $\ldots$ & $\ldots$ & $\ldots$ & $\ldots$ & $\ldots$ & $X$ & $\ldots$ & $\ldots$ \\
\hline PITG_07550_6 & I & $\mathrm{R}$ & M & $\mathrm{L}$ & Q & $\ldots$ & $\ldots$ & $\ldots$ & $\ldots$ & $\ldots$ & $\ldots$ & $\ldots$ & $X$ & $\ldots$ \\
\hline PITG_07550_7 & I & $\mathrm{R}$ & M & $\mathrm{L}$ & $\mathrm{R}$ & $\ldots$ & $\ldots$ & $\ldots$ & $\mathrm{X}$ & $\ldots$ & $\ldots$ & $\ldots$ & $\ldots$ & $\ldots$ \\
\hline PITG_07550_8 & I & Q & $\mathrm{K}$ & $\mathrm{M}$ & Q & $\ldots$ & $\ldots$ & $\ldots$ & $\ldots$ & $\mathrm{X}$ & $\ldots$ & $\ldots$ & $\ldots$ & $\ldots$ \\
\hline PITG_07550_10 & I & Q & $\mathrm{K}$ & $\mathrm{L}$ & $\mathrm{R}$ & $\ldots$ & $\ldots$ & $\ldots$ & $\mathrm{X}$ & $\mathrm{X}$ & $\ldots$ & $\ldots$ & $\ldots$ & $\ldots$ \\
\hline PITG_07550_11 & II & Q & $\mathrm{M}$ & $\mathrm{L}$ & Q & $\ldots$ & $\mathrm{X}$ & $\ldots$ & $\ldots$ & $\ldots$ & $X$ & $\ldots$ & $\ldots$ & $\ldots$ \\
\hline PITG_07550_13 & II & Q & M & $\mathrm{L}$ & Q & $\ldots$ & $\ldots$ & $\ldots$ & $\ldots$ & $\ldots$ & $\ldots$ & $\mathrm{X}$ & $\ldots$ & $\ldots$ \\
\hline PITG_07550_14 & II & $\mathrm{R}$ & $\mathrm{K}$ & $\mathrm{L}$ & $\mathrm{R}$ & $\mathrm{X}$ & $\ldots$ & $\ldots$ & $\ldots$ & $\ldots$ & $\ldots$ & $\mathrm{X}$ & $\ldots$ & $\ldots$ \\
\hline PITG_07550_15 & II & $\mathrm{R}$ & $\mathrm{K}$ & $\mathrm{L}$ & Q & $X$ & $\mathrm{X}$ & $\mathrm{X}$ & $X$ & $\ldots$ & $\mathrm{X}$ & $X$ & $X$ & $X$ \\
\hline
\end{tabular}

${ }^{a}$ Genetic diversity of AvrSmira1 in P. infestans strains. For each obtained genetic variant, the phylogenetic classification, identity of amino acids under diversifying selection, and presence in $P$. infestans strains is presented.

${ }^{\mathrm{b}}$ Broad PITG_07550 sequence.

Table 6. Summary of virulence data on the 3079 population in offspring that was responding versus not responding to the AvrSmiral candidate PITG_ $07550^{\mathrm{a}}$

\begin{tabular}{lcclcccccc}
\hline & \multicolumn{10}{c}{ Phytophthora infestans strains } \\
\cline { 2 - 10 } Population 3079 & $\mathbf{8 9 1 4 8 - 0 9}$ & PIC 99177 & EC1 & $\mathbf{9 0 1 2 8}$ & H30P04 & PIC 99189 & PIC 99183 & IPO 428-2 & IPO-C \\
\hline Response & R & R & R & R-S & R-M-S & R-S & S & S & S \\
No response & R & R-M-S & M-S & S & R-M-S & R & S & S & S \\
\hline
\end{tabular}

${ }^{a}$ Individual plants were scored resistant (R), intermediate (M), or susceptible (S). 
because the AVR profiles of infecting $P$. infestans strains could not accurately be determined. In this study, we took advantage of the $P$. infestans genome sequence and the complete catalogue of RXLR effector genes to successfully apply an effectoromics strategy. We showed that field resistance can be dissected and assessed using pathogen effector assays. The response to AVRSmira2 was significantly correlated with quantitative RpiSmira 2 resistance in the field. This indicates that effectors can serve as absolute markers in field resistance breeding programs. In addition, our results suggest that field resistance shares mechanistic similarities with $R$-gene-based resistance, and might also be mediated by nucleotide-binding site leucinerich repeat (NBS-LRR)-type $R$ genes and perception of RXLR effectors. This is in line with reports that field resistance loci are localized in regions of the potato genome that contain NBS-LRR genes (Leonards-Schippers et al. 1994; Tan et al. 2008) and that potato plants with field and partial resistance mount the HR after penetration of $P$. infestans (Gees and Hohl 1988; Kamoun et al. 1999; Vleeshouwers et al. 2000). Therefore, field resistance may represent a weaker form of $R$-genebased resistance that does not cause a full-blown HR and resistance phenotype upon recognition of the pathogen. Our findings that field resistance of 'Sarpo Mira' is associated with recognition of an RXLR effector opens up new possibilities to further unravel the underlying resistance mechanism.

The newly identified qualitative $R$ gene, Rpi-Smiral, can be exploited in potato breeding. Based on a disomic segregation model and because recognition of AVR3a is in repulsion phase with AVRSmira1-mediated resistance, we hypothesize that Rpi-Smiral most likely localizes near the $R 3 a$ gene cluster on chromosome 11 on a sister chromatid.

In modern late blight management, breeders attempt to preempt the quick defeat of $R$ genes by pyramiding multiple $R$ genes in one cultivar (Jacobsen and Hutten 2006; Pink and Puddephat 1999). In 'Sarpo Mira', the previously defeated $R 3 a$, $R 3 b$, and $R 4$ genes are present and confer full qualitative resistance to avirulent strains in detached-leaf tests, similar to the other qualitative $R$ genes $R 1, R 2$, and $R 3 a$ that have been isolated from $S$. demissum (Ballvora et al. 2002; Huang et al. 2005; Lokossou et al. 2009). In addition to $R 3 a, R 3 b$, and $R 4$, a new race-specific $R$ gene, Rpi-Smiral, was identified in 'Sarpo Mira'. Like the other qualitative $R$ genes from $S$. demissum, Rpi-Smiral was also defeated because strains H30P04, PIC99189, PIC99183, IPO428-2, and IPO-C can fully infect progeny plants that contain Rpi-Smiral. However, from a practical perspective, it should be kept in mind that even such defeated $R$ genes may cause a delay in infection, as reported, for instance, for the Solanum $R 2$ gene (Pilet et al. 2005). In addition, the degree of resistance is dependent on the genotype of the $P$. infestans population, and monitoring for virulence to specific $R$ genes in the local $P$. infestans population can assist $R$ gene deployment (Champouret et al. 2009; Vleeshouwers et al. 2011b).

Sarpo Mira has performed better in the field and has been proposed to be the answer to potato late blight resistance compared with other potato cultivars with combined $R$ genes, such as 'Pentland Dell' $(R 1 R 2 R 3)$ and 'Escort' (R1R2R3R10). Our study clearly demonstrates that 'Sarpo Mira' contains a pyramid of not only four qualitative $R$ genes but also one quantitative field resistance gene. Therefore, late blight resistance of 'Sarpo Mira' may simply be due to a combination of $R$-genetype responses to a set of five RXLR effectors, and evolution of virulence in $P$. infestans may be dependent on epidemiological factors, such as acreage and the pathogen races present in the field. Indeed, our work shows that some isolates, such as IPO-C, are virulent on 'Sarpo Mira' in the lab and in the field. Nonetheless, we now have the molecular markers and effector assays to breed the five resistance genes and improve the agronomic traits of 'Sarpo Mira'. In addition, in the future, the approach of combining qualitative $R$ genes with quantitative ones should be given more consideration in late blight resistance breeding.

\section{MATERIALS AND METHODS}

\section{Plant material.}

The potato 'Sarpo Mira' was crossed with the susceptible $\mathrm{RH}$, a donor of the potato genome sequence (Potato Genome Sequencing Consortium 2011). Thirty genotypes of the resulting 'Sarpo Mira' $\times$ RH population 3079, and parents, were clonally maintained in vitro in sterile jars containing Murashige and Skoog medium (Murashige and Skoog 1962) supplemented with $3 \%(\mathrm{wt} / \mathrm{vol})$ sucrose at $20^{\circ} \mathrm{C}$.

\section{$P$. infestans strains and disease tests.}

$P$. infestans strains were grown on rye agar medium supplemented with $2 \%$ (wt/vol) sucrose (Caten and Jinks 1968) and incubated at $15^{\circ} \mathrm{C}$ in the dark. A list of $P$. infestans strains used in this study is presented in Table 1 . For inoculation of detached leaves, a plate covered with mycelium was flooded with water and the sporangiophore suspension was pipetted into a test tube. After 1 to $2 \mathrm{~h}$ of incubation at $4^{\circ} \mathrm{C}$, zoospores were released and a spore suspension of $5 \times 10^{4}$ spores $/ \mathrm{ml}$ was prepared.

Detached-leaf tests were performed as previously described, with slight modifications (Vleeshouwers et al. 1999). Leaves were detached from mature greenhouse-grown plants, placed in water-saturated florists foam (Oasis) in a tray, and spot inoculated by pipetting 10- $\mu \mathrm{l}$ droplets of the spore suspension on the abaxial side. The trays were covered with transparent bags and incubated in a climate chamber at a photoperiod 16 and $8 \mathrm{~h}$ (day and night, respectively) at $15^{\circ} \mathrm{C}$. At $6 \mathrm{dpi}$, disease phenotypes on the leaves were macroscopically scored. Leaves displaying no disease symptoms or small and localized HR lesions were scored as resistant, whereas leaves containing expanding lesions with massive sporulation were scored susceptible. In some cases, intermediate symptoms occurred, representing less-expanded lesions without or with very limited sporulation. For each $P$. infestans strains, at least five inoculation spots were performed on at least two leaves, resulting in 10 replicates per experiment. All strains were tested twice in independent experiments, except IPO-C, which was tested in a single experiment.

Field trials were performed in summer 2010 and 2011 in Wageningen, The Netherlands. 'Sarpo Mira' parents and progeny genotypes were represented as two-plant plots, which were treated as single experimental units as described by Colon and Budding (1988). Spreader rows consisted of 'Bintje' potato and border rows of 'Nicola' potato. At nightfall, a zoospore suspension of IPO-C was sprayed on the potato field using a tractor with two spraying arms. Disease assessments were made by estimating the percentage of leaf area covered with late blight lesions for each plot. From these readings, the AUDPC was calculated (Fry 1978). In 2010, disease assessments were made between 22 and 47 dpi and, in 2011, between 8 and 20 dpi.

\section{Effector screening.}

A genome-wide collection of RXLR effectors was selected from the $P$. infestans genome sequence based on presence of a predicted signal peptide, an RXLR motif, and an elevated gene expression at 6 hpi to 3 dpi (Haas et al. 2009). Sequences coding for putative signal peptides were excluded and replaced with an ATG codon. The coding sequences were synthesized by GenScript Inc. (Piscataway, NJ, U.S.A.) in between AttL1 
and AttL2 gateway recombination sites and cloned into pUC57. Subsequently, effectors were subcloned into pK7WG2 using LR clonase (Invitrogen, Carlsbad, CA, U.S.A) and were transformed into Agrobacterium tumefaciens AGL1, pSoup, and pVirG cells by electroporation.

Agroinfiltration was performed as previously described (van der Hoorn et al. 2000; Vleeshouwers and Rietman 2009). Briefly, A. tumefaciens strains were grown to a desired optical density at $600 \mathrm{~nm}$ of 0.3 and leaf panels of 2- to 3-week-old potato plants were infiltrated with the A. tumefaciens suspensions. Symptoms were monitored from 2 to 6 days postinfiltration.

\section{Genetic variation of AvrSmira1.}

AvrSmiral variants were amplified from genomic DNA of $P$. infestans strains with the forward (GGGGACAAGTTTgtaca aaaaagcaggctATatgGCAACTGTGACCAAGGTATCG) and reverse (GGGGACCACTTTGTACAAGaaagctgggtATTATCCG GAGGGGTTTAGC) primers using Phire and Phusion polymerase (Finnzymes). PITG_7550_1 and PITG_10 were also detected in the T30-4 genome trace archive at the National Center for Biotechnology Information (Robbertse and Tatusova 2011) using BlastN and consequent contig assembly using DNAstar v9. Amplicons were cloned into pK7WG2 and transformed to A. tumefaciens AGL1. DNA sequences were analyzed using DNAstar v9. Phylogenetic analyses of AvrSmiral sequences were conducted using the minimum evolution method, neighbor joining, and maximum parsimony using MEGA version 5 (Tamura et al. 2011). DNA sequences of the 11 AvrSmira variants were subjected to positive selection analysis using the software package JCoDA (Steinway et al. 2010), in which the PAML v.4 codeml program (Yang 2007) was integrated. Predictions for WY domains were performed with the RADAR repeat finder EMBL server.

\section{ACKNOWLEDGMENTS}

We thank G. Kessel (Plant Research International, The Netherlands), F. Govers (Wageningen University, The Netherlands), and P. Birch (James Hutton Institute, Dundee) for kindly providing P. infestans strains; P. Birch for pleasant collaborations on the effector set; H.-J. Kim for technical assistance; S. Raffaele for professional (and arty) contributions; and the Dutch Umbrella Program, DuRPh project, and Gatsby Charitable Foundation for financial support.

\section{LITERATURE CITED}

Armstrong, M. R., Whisson, S. C., Pritchard, L., Bos, J. I. B., Venter, E., Avrova, A. O., Rehmany, A. P., Bohme, U., Brooks, K., Cherevach, I., Hamlin, N., White, B., Frasers, A., Lord, A., Quail, M. A., Churcher, C., Hall, N., Berriman, M., Huang, S., Kamoun, S., Beynon, J. L., and Birch, P. R. J. 2005. An ancestral oomycete locus contains late blight avirulence gene Avr3a, encoding a protein that is recognized in the host cytoplasm. Proc. Natl. Acad. Sci. U.S.A.102:7766-7771.

Ballvora, A., Ercolano, M. R., Weiss, J., Meksem, K., Bormann, C. A., Oberhagemann, P., Salamini, F., and Gebhardt, C. 2002. The Rl gene for potato resistance to late blight (Phytophthora infestans) belongs to the leucine zipper/NBS/LRR class of plant resistance genes. Plant J. 30:361-371.

Black, W., Mastenbroek, C., Mills, W. R., and Peterson, L. C. 1953. A proposal for an international nomenclature of races of Phytophthora infestans and of genes controlling immunity in Solanum demissum derivatives. Euphytica 2:173-178.

Caten, C. E., and Jinks, J. L. 1968. Spontaneous variability of single isolates of Phytophthora infestans I. Cultural variation. Can. J. Bot. 46:329-347.

Champouret, N., Bouwmeester, K., Rietman, H., van der Lee, T., Maliepaard, C., Heupink, A., van de Vondervoort, P. J., Jacobsen, E., Visser, R. G., van der Vossen, E. A., Govers, F., and Vleeshouwers, V. G. A. A. 2009. Phytophthora infestans isolates lacking class I ipiO variants are virulent on Rpi-blb1 potato. Mol. Plant-Microbe Interact. 22:1535-1545.
Colon, L. T., and Budding, D. J. 1988. Resistance to late blight (Phytophthora infestans) in ten wild Solanum species. Euphytica Suppl.:77-86.

Ellis, J. G., Rafiqi, M., Gan, P., Chakrabarti, A., and Dodds, P. N. 2009. Recent progress in discovery and functional analysis of effector proteins of fungal and oomycete plant pathogens. Curr. Opin. Plant Biol. 12:399-405.

Flier, W. G., Grunwald, N. J., Kroon, L., van den Bosch, T. B. M., Garay Serrano, E., Lozoya Saldana, H., Bonants, P. J. M., and Turkensteen, L. J. 2002. Phytophthora ipomoeae sp. nov., a new homothallic species causing leaf blight on Ipomoea longipedunculata in the Toluca Valley of central Mexico. Mycol. Res. 106 Part 7:848-856.

Flier, W. G., Grunwald, N. J., Kroon, L., Sturbaum, A. K., van den Bosch, T. B. M., Garay Serrano, E., Lozoya Saldana, H., Fry, W. E., and Turkensteen, L. J. 2003. The population structure of Phytophthora infestans from the Toluca Valley of central Mexico suggests genetic differentiation between populations from cultivated potato and wild Solanum spp. Phytopathology 93:382-390.

Fry, W. E. 1978. Quantification of general resistance of potato cultivars and fungicide effects for integrated control of potato late blight. Phytopathology 68:1650-1655.

Fry, W. E. 2008. Phytophthora infestans: The plant (and $R$ gene) destroyer. Mol. Plant Pathol. 9:385-402.

Gebhardt, C., and Valkonen, J. P. 2001. Organization of genes controlling disease resistance in the potato genome. Annu. Rev. Phytopathol. 39:79102.

Gees, R., and Hohl, H. R. 1988. Cytological comparison of specific (R3) and general resistance to late blight in potato leaf tissue. Phytopathology 78:350-357.

Haas, B. J., Kamoun, S., Zody, M. C., Jiang, R. H., Handsaker, R. E., Cano, L. M., Grabherr, M., Kodira, C. D., Raffaele, S., Torto-Alalibo, T., Bozkurt, T. O., Ah-Fong, A. M., Alvarado, L., Anderson, V. L., Armstrong, M. R., Avrova, A., Baxter, L., Beynon, J., Boevink, P. C., Bollmann, S. R., Bos, J. I., Bulone, V., Cai, G., Cakir, C., Carrington, J. C., Chawner, M., Conti, L., Costanzo, S., Ewan, R., Fahlgren, N., Fischbach, M. A., Fugelstad, J., Gilroy, E. M., Gnerre, S., Green, P. J., Grenville-Briggs, L. J., Griffith, J., Grunwald, N. J., Horn, K., Horner, N. R., Hu, C. H., Huitema, E., Jeong, D. H., Jones, A. M., Jones, J. D., Jones, R. W., Karlsson, E. K., Kunjeti, S. G., Lamour, K., Liu, Z., Ma, L., Maclean, D., Chibucos, M. C., McDonald, H., McWalters, J., Meijer, H. J., Morgan, W., Morris, P. F., Munro, C. A., O’Neill, K., OspinaGiraldo, M., Pinzon, A., Pritchard, L., Ramsahoye, B., Ren, Q., Restrepo, S., Roy, S., Sadanandom, A., Savidor, A., Schornack, S., Schwartz, D. C., Schumann, U. D., Schwessinger, B., Seyer, L., Sharpe, T., Silvar, C., Song, J., Studholme, D. J., Sykes, S., Thines, M., van de Vondervoort, P. J., Phuntumart, V., Wawra, S., Weide, R., Win, J., Young, C., Zhou, S., Fry, W., Meyers, B. C., van West, P., Ristaino, J., Govers, F., Birch, P. R., Whisson, S. C., Judelson, H. S., and Nusbaum, C. 2009. Genome sequence and analysis of the Irish potato famine pathogen Phytophthora infestans. Nature 461:393-398.

Halterman, D. A., Chen, Y., Sopee, J., Berduo-Sandoval, J., and SanchezPerez, A. 2010. Competition between Phytophthora infestans effectors leads to increased aggressiveness on plants containing broad-spectrum late blight resistance. PLoS One 5:e10536. Published online.

Haverkort, A., Struik, P., Visser, R., and Jacobsen, E. 2009. Applied biotechnology to combat late blight in potato caused by Phytophthora infestans. Potato Res. 52:249-264.

Huang, S., van der Vossen, E. A. G., Kuang, H., Vleeshouwers, V. G. A. A. Zhang, N., Borm, T. J. A., van Eck, H. J., Baker, B., Jacobsen, E., and Visser, R. G. F. 2005. Comparative genomics enabled the isolation of the $R 3 a$ late blight resistance gene in potato. Plant J. 42:251-261.

Jacobsen, E., and Hutten, R. 2006. Stacking resistance genes in potato by cisgenesis instead of introgression breeding. Pages 46-57 in: Potato Developments in a Changing Europe. N. U. Haase and A. J. Haverkort, eds. Wageningen Academic Publishers. Wageningen, The Netherlands.

Jones, J.D. 2001. Putting knowledge of plant disease resistance genes to work. Curr. Opin. Plant Biol. 4:281-287.

Kamoun, S., Huitema, E., and Vleeshouwers, V. G. A. A. 1999. Resistance to oomycetes: A general role for the hypersensitive response? Trends Plant Sci. 4:196-200.

Kim, H.-J., Lee, H.-R., Kwang-Ryong, J., Mortazavian, S. M. M., Huigen, D. J., Evenhuis, B., Kessel, G., Visser, R. G. F., Jacobsen, E., and Vossen, J. H. 2011. Broad spectrum late blight resistance in potato differential set plants $\mathrm{Ma} R 8$ and $\mathrm{Ma} R 9$ is conferred by multiple stacked $R$ genes. Theor. Appl. Genet. 124:923-935.

Leonards-Schippers, C., Gieffers, W., Schafer Pregl, R., Ritter, E., Knapp, S. J., Salamini, F., and Gebhardt, C. 1994. Quantitative resistance to Phytophthora infestans in potato: A case study for QTL mapping in an allogamous plant species. Genetics 137:67-77.

Li, G., Huang, S., Guo, X., Li, Y., Yang, Y., Guo, Z., Kuang, H., Rietman, H., Bergervoet, M., Vleeshouwers, V. G. A. A., van der Vossen, E. A. 
G., Qu, D.-Y., Visser, R. G. F., Jacobsen, E., and Vossen, J. 2011. Cloning and characterization of $R 3 b$; Members of the $R 3$ superfamily of late blight resistance genes show sequence and functional divergence. Mol. Plant-Microbe Interact. 24 1132-1142.

Lokossou, A. A., Park, T. H., van Arkel, G., Arens, M., Ruyter-Spira, C., Morales, J., Whisson, S. C., Birch, P. R. J., Visser, R. G. F., Jacobsen, E., and van Der Vossen, E. A. G. 2009. Exploiting knowledge of $R / A v r$ genes to rapidly clone a new LZ-NBS-LRR family of late blight resistance genes from potato linkage group IV. Mol. Plant-Microbe Interact. 22:630-641.

Malcolmson, J. F. 1969. Races of Phytophthora infestans occurring in Great Britain. Trans. Br. Mycol. Soc. 53:417-423.

McDonald, B. A., and Linde, C. 2002. Pathogen population genetics, evolutionary potential, and durable resistance. Annu. Rev. Phytopathol. 40:349-379.

Müller, K. O., and Black, W. 1952. Potato breeding for resistance to blight and virus diseases during the last hundred years. Z. Pflanzenzuecht. 31:305-318

Murashige, T., and Skoog, F. 1962. A revised medium for rapid growth and bioassays with tobacco tissue cultures. Physiol. Plant. 15:473-497.

Oh, S.-K., Young, C., Lee, M., Oliva, R., Bozkurt, T. O., Cano, L. M., Win, J., Bos, J. I. B., Liu, H.-Y., van Damme, M., Morgan, W., Choi, D., Van der Vossen, E. A. G., Vleeshouwers, V. G. A. A., and Kamoun, S. 2009. In planta expression screens of Phytophthora infestans RXLR effectors reveal diverse phenotypes, including activation of the Solanum bulbocastanum disease resistance protein Rpi-blb2. Plant Cell 21:2928-2947.

Park, T. H., Vleeshouwers, V. G. A. A., Jacobsen, E., van der Vossen, E. and Visser, R. G. F. 2009. Molecular breeding for resistance to Phytophthora infestans (Mont.) de Bary in potato (Solanum tuberosum L.): A perspective of cisgenesis. Plant Breed. 128:109-117.

Pilet, F., Pelle, R., Ellisseche, D., and Andrivon, D. 2005. Efficacy of the $R 2$ resistance gene as a component for the durable management of potato late blight in France. Plant Pathol. 54:723-732.

Pink, D., and Puddephat, I. 1999. Deployment of disease resistance genes by plant transformation-a 'mix and match' approach. Trends Plant Sci. 4:71-75.

Potato Genome Sequencing Consortium. 2011. Genome sequence and analysis of the tuber crop potato. Nature 475:189-195.

Qutob, D., Tedman-Jones, J., Dong, S., Kuflu, K., Pham, H., Wang, Y., Dou, D., Kale, S. D., Arredondo, F. D., Tyler, B. M., and Gijzen, M. 2009. Copy number variation and transcriptional polymorphisms of Phytophthora sojae RXLR effector genes Avrla and Avr3a. PLoS ONE 4. Published online.

Raffaele, S., Farrer, R. A., Cano, L. M., Studholme, D. J., MacLean, D., Thines, M., Jiang, R. H. Y., Zody, M. C., Kunjeti, S. G., Donofrio, N. M., Meyers, B. C., Nusbaum, C., and Kamoun, S. 2010. Genome evolution following host jumps in the Irish potato famine pathogen lineage. Science 330:1540-1543.

Robbertse, B., and Tatusova, T. 2011. Fungal genome resources at NCBI Mycology 2:142-160.

Solomon-Blackburn, R. M., Stewart, H. E., and Bradshaw, J. E. 2007. Distinguishing major-gene from field resistance to late blight (Phytophthora infestans) of potato (Solanum tuberosum) and selecting for high levels of field resistance. Theor. Appl. Genet. 115:141-149.

Steinway, S., Dannenfelser, R., Laucius, C., Hayes, J., and Nayak, S. 2010. JCoDA: A tool for detecting evolutionary selection. BMC Bioinf. $11: 284$

Stewart, H. E., Bradshaw, J. E., and Pande, B. 2003. The effect of the presence of $R$ genes for resistance to late blight (Phytophthora infestans) of potato (Solanum tuberosum) on the underlying level of field resistance. Plant Pathol. 52:193-198

Tamura, K., Peterson, D., Peterson, N., Stecher, G., Nei, M., and Kumar, S. 2011. MEGA5: Molecular evolutionary genetics analysis using maximum likelihood, evolutionary distance, and maximum parsimony methods. Mol. Biol. Evol. 28:2731-2739.

Tan, M. Y. A., Hutten, R. C. B., Celis, C., Park, T. H., Niks, R. E., Visser, R. G. F., and van Eck, H. J. 2008. The Rpi-mcdl locus from Solanum microdontum involved in resistance to Phytophthora infestans, causing a delay in infection, maps on potato chromosome 4 in a cluster of NBS-
LRR genes. Mol. Plant-Microbe Interact. 21:909-918.

van der Hoorn, R. A. L., Laurent, F., Roth, R., and de Wit, P. J. G. M. 2000. Agroinfiltration is a versatile tool that facilitates comparative analyses of Avr $9 / C f$-9-induced and Avr4/Cf-4-induced necrosis. Mol. Plant-Microbe Interact. 13:439-446.

van der Lee, T., Testa, A., van 't Klooster, J., van den Berg Velthuis, G., and Govers, F. 2001. Chromosomal deletion in isolates of Phytophthora infestans correlates with virulence on R3, R10, and R11 potato lines. Mol. Plant-Microbe Interact. 14:1444-1452.

Van Der Plank, J. 1971. Stability of resistance to Phytophthora infestans in cultivars without $R$ genes. Potato Res. 14:263-270.

van Poppel, P. M. J. A., Guo, J., van de Vondervoort, P. J., Jung, M. W., Birch, P. R., Whisson, S. C., and Govers, F. 2008. The Phytophthora infestans avirulence gene Avr4 encodes an RXLR-dEER effector. Mol. Plant-Microbe Interact. 21:1460-1470.

van Poppel, P. M. J. A., Huigen, D. J., and Govers, F. 2009. Differential recognition of Phytophthora infestans races in potato $R 4$ breeding lines. Phytopathology 99:1150-1155.

van West, P., de Jong, A. J., Judelson, H. S., Emons, A. M. C., and Govers, F. 1998. The ipiO gene of Phytophthora infestans is highly expressed in invading hyphae during infection. Fungal Genet. Biol. 23:126-138.

Vleeshouwers, V. G. A. A., and Rietman, H. 2009. In planta expression systems. Pages 455-475 in: Oomycete genetics and Genomics: Diversity, Interactions, and Research Tools. K. Lamour and S. Kamoun, eds. Wiley-Blackwell, Hoboken, NJ, U.S.A.

Vleeshouwers, V. G. A. A., van Dooijeweert, W., Keizer, L. C. P., Sijpkes, L., Govers, F., and Colon, L. T. 1999. A laboratory assay for Phytophthora infestans resistance in various Solanum species reflects the field situation. Eur. J. Plant Pathol. 105:241-250.

Vleeshouwers, V. G. A. A., van Dooijeweert, W., Govers, F., Kamoun, S. and Colon, L. T. 2000. The hypersensitive response is associated with host and nonhost resistance to Phytophthora infestans. Planta 210:853864.

Vleeshouwers, V. G. A. A., Rietman, H., Krenek, P., Champouret, N., Young, C., Oh, S.-K., Wang, M., Bouwmeester, K., Vosman, B., Visser, R. G. F., Jacobsen, E., Govers, F., Kamoun, S., and Van der Vossen, E. A. G. 2008. Effector genomics accelerates discovery and functional profiling of potato disease resistance and Phytophthora infestans avirulence genes. PLoS ONE 3:e2875. Published online.

Vleeshouwers, V. G. A. A., Finkers, R., Budding, D. J., Visser, M., Jacobs, M. M. J., van Berloo, R., Pel, M., Champouret, N., Bakker, E., Krenek, P., Rietman, H., Huigen, D. J., Hoekstra, R., Goverse, A., Vosman, B., Jacobsen, E., and Visser, R. G. F. 2011a. SolRgene: An online database to explore disease resistance genes in tuber-bearing Solanum species. BMC Plant Biology 11:116. Published online.

Vleeshouwers, V. G. A. A., Raffaele, S., Vossen, J., Champouret, N., Oliva, R., Segretin, M. E., Rietman, H., Cano, L. M., Lokossou, A. A., Kessel, G. J. T., Pel, M., and Kamoun, S. 2011b. Understanding and exploiting late blight resistance in the age of effectors. Annu. Rev. Phytopathol. 49:507-531.

Wastie, R. 1991. Breeding for resistance. Pages 193-224 in: Phytophthora infestans, the Cause of Late Blight of Potato. D. Ingram and P. Williams, eds. Academic Press, London.

White, S., and Shaw, D. 2010. Breeding for host resistance: The key to sustainable potato production. In: Twelfth EuroBlight Workshop. A Lees, J. G. Hansen, and H. Schepers, eds. PPO, Arras, France.

Win, J., Morgan, W., Bos, J., Krasileva, K. V., Cano, L. M., ChaparroGarcia, A., Ammar, R., Staskawicz, B. J., and Kamoun, S. 2007. Adaptive evolution has targeted the C-terminal domain of the RXLR effectors of plant pathogenic oomycetes. Plant Cell 19:2349-2369.

Yang, Z. 2007. PAML 4: Phylogenetic analysis by maximum likelihood. Mol. Biol. Evol. 24:1586-1591.

\section{AUTHOR-RECOMMENDED INTERNET RESOURCES}

The Sárvári Research Trust website: www.sarvari-trust.org

Center for Biological Sequence Analysis SignalPv2.0 server: www.cbs.dtu.dk/services/SignalP-2.0 